\title{
931 UNDER-UTILISATION OF INTERNAL EMPLOYEE ASSISTANCE PROGRAMME (EAP) SERVICES BY THE SOUTH AFRICAN POLICE SERVICE IN LEPHALALE, LIMPOPO PROVINCE
}

\section{Mmaphuti Percy Dipela, Sello Sithole}

Dr Mmaphuti Percy Dipela, School of Social Sciences, University of South Africa, Pretoria, South Africa.

Prof. Sello Sithole, School of Social Sciences, University of Limpopo, Sovenga, South Africa.

Mmaphuti Percy Dipela: dipelmp1@unisa.ac.za

Sello Sithole: sello.sithole@ul.ac.za

Mmaphuti Percy Dipela: ORCiD: 0000-0003-3882-6601

Sello Sithole, ORCiD: 0000-0001-9990-8868

\section{ABSTRACT}

An employee assistance programme (EAP) is a service provided by an employer to employees who experience personal problems. Its utilisation becomes a challenge when the targeted population prefers to use alternative services to this programme specifically earmarked for them. Such a situation motivated this quantitative research aimed to evaluate the utilisation of the employee assistance programme in the South African Police Service (SAPS) in the Waterberg district of Limpopo Province. A systematic sample comprising of 189 respondents was drawn from the total population of 398 employees. The study revealed that the employees' awareness of the programme was very low.

Keywords: employee assistance practitioner, employee assistance programme, employees, South African Police Service, underutilisation, workplace 



\title{
UNDER-UTILISATION OF INTERNAL EMPLOYEE ASSISTANCE PROGRAMME (EAP) SERVICES BY THE SOUTH AFRICAN POLICE SERVICE IN LEPHALALE, LIMPOPO PROVINCE
}

\author{
Mmaphuti Percy Dipela, Sello Sithole \\ Dr Mmaphuti Percy Dipela, School of Social Sciences, University of South Africa, Pretoria, South \\ Africa.
}

Prof. Sello Sithole, School of Social Sciences, University of Limpopo, Sovenga, South Africa.

\section{INTRODUCTION}

The South African Police Service management has the responsibility to provide psycho-social services to enhance the health and wellness of their employees (Csiernik \& Csiernik, 2012). One way of ensuring the enhancement of health and wellness of employees in an organisation is to establish an employee assistance programme (EAP) (Grobler \& Joubert, 2012; Leonard \& Terblanche, 2020). The nature of the work carried out by SAPS employees and its impact on them place SAPS under the obligation to provide employee assistance services to them and their families. SAPS employees are confronted with many severe situations that discourage them and create mental, emotional and spiritual burdens for them (Abdulla, Djebarni \& Mellahi, 2011; Maynard, 2019; Mohajane, 2017). The EAP in Lephalale was officially launched in 2005. Prior to that, SAPS employees received services from Modimolle SAPS, which is $200 \mathrm{~km}$ away from Lephalale. Despite the SAPS management having devoted substantial resources to ensure the availability of EAP services for employees, the programme is not utilised fully. As far as could be established, since the programme was launched in Lephalale, it has never been evaluated. In addition to this, the emergence of disturbing trends such as the use of alternative social services by SAPS personnel prompted this study.

The literature alludes to the fact that police officers are reluctant to make use of internal EAP services because of the profession's macho image as well as the perception, false or otherwise, that personal information might not be treated confidentially (Grobler \& Joubert, 2012; Jacobson, Jones \& Bowers, 2011; Rajin, 2012; Sattigeri, 2016). An EAP can become an important service in an organisation to help employees balance their work demands and their personal life, and it can also support the employer's goals for achieving improved levels of productivity (Csiernik \& Csiernik, 2012; Grobler \& Joubert, 2012; Frey, Pompe, Sharar, Imboden \& Bloom, 2018).

\section{PROBLEM STATEMENT}

Notwithstanding the acknowledgement of the importance of human capital for employees by government institutions such as the South African Police Service in the Lephalale Municipality, the contribution of an EAP as a tool for employee wellness is still not well understood, even though considerable research has been undertaken on its functioning and success (Frey et al., 2018; Dimoff \& Kelloway, 2019). The first named author in Frey et al. (2018) was attached to the Department of Social Development (DSD) in Lephalale, which offers social work services to the community. Frey observed first-hand that police officers preferred to make use of DSD services rather than the internal EAP within SAPS, as he saw a considerable number of clients from the SAPS during his time of duty as a social worker at the DSD (Frey et al., 2018). This could suggest that SAPS employees did not make adequate use of the EAP services available to them, which in turn prompted the researcher to undertake an investigation to establish the reasons for this.

As is confirmed by other researchers, the employees of SAPS who used the DSD social work services presented problems such as poor financial management, family problems, workplace stress, substance abuse and other personal problems which resort under the ambit of EAP (Grobler \& Joubert, 2012; Leonard \& Terblanche, 2020). Out of interest, the researcher conducted an informal investigation with three SAPS employees. One of these officers mentioned that it took her eleven months to become aware 
that there was an EAP service within her workplace (SAPS), because it was never formally introduced to her and she had never been informed about this at the start of her employment. The second person mentioned that he was aware that there is an employee assistance practitioner, but he did not have clarity on the role of this person. The third SAPS employee mentioned that he knew there was an EAP practitioner at their workplace, but he did not think he could consult him, because the EAP office was always open and full of people. Consequently, he feared his private information might not be kept confidential as he suspected the EAP practitioner did not have an office of his own. The researcher therefore decided to investigate the apparent under-utilisation of the EAP of the South African Police Service in Lephalale.

\section{AIM AND OBJECTIVES OF THE STUDY}

Against the above background, the focus of this investigation was on the under-utilisation of the employee assistance programme at Lephalale SAPS; accordingly, the following research question was addressed:

What are the causes of the under-utilisation of the EAP of the South African Police Service in Lephalale and how can this be addressed?

The goal of the research was to identify and describe the causes of the under-utilisation of the EAP of the South African Police Service in Lephalale and offer suggestions as to how this can be addressed.

The main objectives of the study in pursuing this goal were the following:

- To describe the influence of programme awareness, understanding and knowledge about it, as well as ascertain the accessibility of EAP services to SAPS members in the context of its utilisation;

- To determine possible reasons for the under-utilisation of the EAP by the SAPS members;

- To offer suggestions as to how the under-utilisation of the EAP can be addressed.

\section{THEORETICAL FRAMEWORK}

The study is based on programme evaluation theory to evaluate the utilisation of the SARS EAP at Lephalale, focusing on evaluating the factors that hinder the effective utilisation of the EAP. Specific attention was given to investigating SAPS employees' awareness of the programme, their understanding of it, the programme utilisation and its accessibility. According to Rossi, Lipsey and Freeman (2004), the historical roots of programme evaluation theory extend back to the $17^{\text {th }}$ century. At that time, the most significant attempts were directed at assessing the extent to which literacy, occupational training programmes and public health initiatives reduced mortality and morbidity from infectious diseases. In other words, evaluation originally focused on measuring the attainment of goals and objectives.

According to Mark, Henry and Julnes (2000), programme evaluation in principle has a broad scope. Mark et al. (2000) identified concepts that can be evaluated, which include: programmes, policies, products, personnel, performance and proposals. Mark et al. (2000) elaborate on the following approaches in programme evaluation:

- The theory-driven approach: according to this approach, evaluators should begin by identifying a programme theory that is a model of a mechanism that links programme activities and outcomes. The use of this programme theory guides the evaluation design;

- The utilisation-focused evaluation: in this approach, evaluators identify the intended users and their use of the programme, and then select methods of inquiry to match those users. Success in this approach is explicitly defined by whether the intended utilisation takes place or not.

The researcher adopted the utilisation-focused evaluation approach for this project. According to De Vos, Strydom, Fouché \& Delport (2011), one way of studying programme utilisation is to gather detailed descriptive information about what the programme is doing. Utilisation evaluation answers the following 
questions: What do clients in the programme experience? What services are provided to clients? How is the programme organised? Utilisation evaluation includes attending to the inputs, activities and process of the programme as a way of informing decision makers about what is going on in the programme and how the programme has developed.

The rationale for using this approach was based on findings that the ability to communicate to employees what services are available through the company's EAP and what steps employees need to take in order to access the services are essential to successful EAP implementation/operation. The researcher further contends that misinterpretation and lack of understanding of EAPs have been found to inhibit utilisation. Emanating from this, the researcher embraces the notion that it is important when one conducts an evaluation of this nature to take into consideration the employees' overall knowledge of the EAP and their access to the EAP, since these factors can hinder or encourage the use of EAP services (Johnson, 2011; Yan \& Yan, 2013, Sattigeri, 2016).

\section{RESEARCH APPROACH AND METHODOLOGY}

In this study the researcher adopted a quantitative approach which assisted in the collection and analysis of numerical data. Merga and Roni (2018) describe the quantitative research method as explaining an issue or phenomenon by gathering data in numerical form and analysing it with the aid of mathematical methods, particularly statistics.

\section{Research design}

A descriptive survey design was used in this study. Descriptive surveys are used mainly to collect data from large samples, but also to present participants with a series of questions to be answered which may elicit facts, attitudes, beliefs, prejudices, preferences or opinions (Leedy \& Ormrod, 2005; Rutberg \& Bouikidis, 2018).

\section{Study population}

The research population of this study consisted of 397 SAPS employees at police stations in Lephalale. The purpose of using a large number of respondents was to have a better understanding and a broader view of the effectiveness of EAP services across all the SAPS employees, irrespective of the position they occupied.

\section{Sampling procedure}

The study used systematic random sampling to compile the sample. The use of a systematic sample provides a convenient way to draw a sample from a large identified population when a printed list (sampling frame) of that population is available (Bless, Higson-Smith \& Sithole, 2013: De Vos et al., 2011). In systematic sampling, every $n t h$ name is selected from a list; the interval between names on the list is usually determined by dividing the number of persons desired in the sample from the entire population (De Vos et al., 2011).

In this research the researcher requested and obtained a name list of all the employees within the Lephalale SAPS cluster from the Human Resource Office. Some of the employees are employed in terms of South African Police Service Act 68 of 1995 (RSA, 1995) and others in terms of the Public Service Act 103 of 1994 (RSA, 1994). The total population was 397 and every second person appearing on the list was selected. This came to a total of 198 SAPS employees. However, only 189 employees were available during data collection. Therefore, a systematic sample comprising of 189 respondents was drawn from the total population of 397 employees.

\section{Data-collection instrument}

The researcher designed and used a questionnaire as the instrument for data collection, based on the literature studied. Quantitative data-collection methods often employ measuring instruments in the form of questionnaires, checklists and indexes to obtain the required data (De Vos et al., 2011; Rutberg \& 
Bouikidis, 2018). For the purposes of this study, the researcher used a self-developed questionnaire based on the literature studied to obtain data from SAPS employees after receiving the necessary permission from SAPS management to do so. In addition, ethical clearance was granted from the University of Limpopo's Ethics Committee. The questionnaire was used to elicit information from the employees on the effectiveness of EAP by focusing on their awareness, knowledge, understanding of and satisfaction with the EAP service. The respondents reported on their own experiences, knowledge and awareness by responding to the questions that appeared on the questionnaire.

\section{Data analysis}

The researcher used a descriptive statistical analysis to manage and analyse the data obtained. According to McCledon (2004) and Mishra, Pandey, Singh, Gupta, Sahu and Keshri (2019), statistical analysis consists of two somewhat distinct tasks. The first task is the description or summary of the observed sample data and the second is using these sample observations to make estimates about the characteristics of the larger population from which the sample was selected. These statistical tasks are called descriptive statistics.

\section{Description of the sample}

In this study the respondents' ages ranged between 20 and 55 years, with the majority (60\%) being youths, In the South African context a youth is a person under the age of 35 years. The respondents consisted of $65 \%$ males and $35 \%$ females. The reason for this may be historical in nature, as in the past staff recruitment within the SAPS preferred males over females. The respondents had varying years of work experience. Sixty-four percent $(64 \%)$ of the participants had five and more years of experience, while $34 \%$ reported having two to five years of experience in their specific fields of work. A significantly smaller portion (2\%) had only accumulated one to two years of experience at the time of data collection. The study revealed that the majority of respondents (48\%) were married, with a lower percentage (18\%) cohabitating. The study revealed that the majority of employees $(89 \%)$ had dependants and a lower percentage $(11 \%)$ had no dependants.

\section{DISCUSSION OF THE FINDINGS}

\section{Awareness of EAP}

Table 1 reflects the responses of SAPS employees from Lephalale regarding their awareness of EAP services at their workplace.

TABLE 1: EMPLOYEES' AWARENESS OF EAP

\begin{tabular}{|l|l|l|}
\hline OPTION & $\mathbf{N}=$ & $\%$ \\
\hline Aware & 107 & 57 \\
\hline Not aware & 73 & 38 \\
\hline Not sure & 09 & 05 \\
\hline TOTAL & $\mathbf{1 8 9}$ & $\mathbf{1 0 0}$ \\
\hline
\end{tabular}

It is evident from Table 1 that a significant number of the employees (57\%), more than half of the sample, were aware of the EAP's existence. However, despite the fact that the programme had already been launched in 2005, a significant percentage (38\%) were not aware of it, while $5 \%$ were not sure about its existence. Cognisance is taken of the fact that within the SAPS there are numerous officers who sometimes work night shifts, whereas the EAP practitioner is on service only during the day. It is important for the EAP practitioner to ensure that the programme is marketed intensively through posters, ensuring that EAP services are noted on the payslips of SAPS employees and also marketed electronically through messages and emails.

In a follow-up question on how SAPS employees became aware of the programme, the majority (71\%) of employees reported that they had become aware of the EAP through meetings, while a smaller number 
of employees (20\%) were informed about it by their colleagues. Other employees (9\%) became aware of the EAP services through their managers. In the literature, conducting information meetings is regarded as one of the more effective strategies used to inform employees about the existence of an EAP (Attridge, 2018; Stone, 2011; Zeng, Guo, Lu, Han, Chen \& Ling, 2014). Even though meetings served as information points about the EAP, it may be inferred that such platforms would not perforce provide deep knowledge of what the programme entails and its benefits. Attridge (2018) also indicates that an EAP can provide good services, but that a lack of knowledge of such services may imply under-utilisation thereof. This means that if the employees are not aware of the existence of the programme, it may not be utilised sufficiently and thus its impact on the organisation might not be visible. This will result in the programme being ineffective. If employees are not aware of the availability of such services within their own organisation, they may seek professional assistance elsewhere.

\section{Visits to EAP office}

In order to determine the willingness of employees to utilise EAP services, information was obtained about the respondents' visits to the EAP office. Figure 1 indicates whether participants had visited the EAP office.

\section{FIGURE 1 \\ EAP VISITS BY RESPONDENTS}

\section{EAP visits by participants}

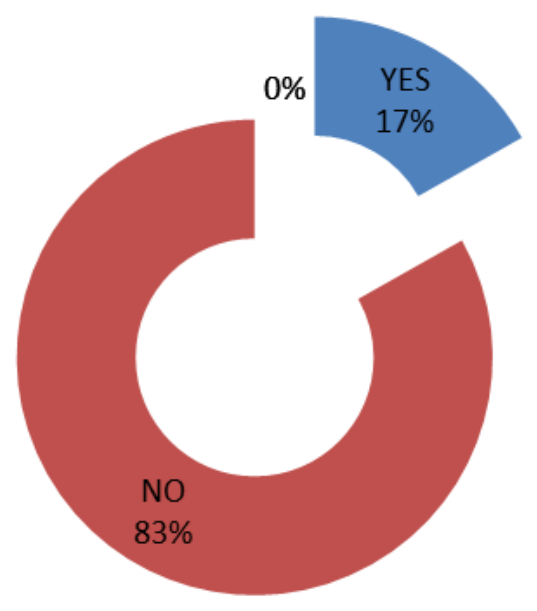

The majority of respondents ( $83 \%$ ) had never visited the EAP office, whereas only $17 \%$ indicated that they had visited the EAP office. It appears to the researcher that the SAPS employees in Lephalale were not fully aware of the benefits that the EAP could offer them. This could be a reason why many of them visited the Department of Social Development to seek services. Given this finding, it is very concerning that employees appeared not to be interested in visiting the SAPS EAP office, even though the majority of them were aware of the programme. Moreover, it is evident that the programme did not actually reach its targeted employees as indicated above and that this negatively impacted on the utilisation of the programme.

The researcher believes the programme can only be regarded as effective when it reaches the majority of employees for whom it is intended. For the effective utilisation of EAP services, it is imperative for EA practitioners, SAPS management and union members to fully encourage employees to utilise the services available to them within the organisation, emphasising that the services are for their own benefit. The researcher further agrees with Stone (2011) and Frey et al. (2018) that employees need to understand the 
rationale for the existence of the EAP in the workplace, namely that it was established to assist employees in dealing with a range of issues and challenges they may be facing that could be detrimental to their work-related responsibilities. This means that visiting the EAP office for assistance will help employees to deal with both personal and work-related problems, thereby also enhancing the EAP's effectiveness.

\section{Visits to EAP in future}

The pie-chart below (Figure 2) shows the willingness of SAPS employees at Lephalale to utilise the EAP services available to them in the future.

\section{FIGURE 2}

\section{WILLINGNESS TO VISIT EAP IN FUTURE}

\section{Willingness to visit EAP in future}

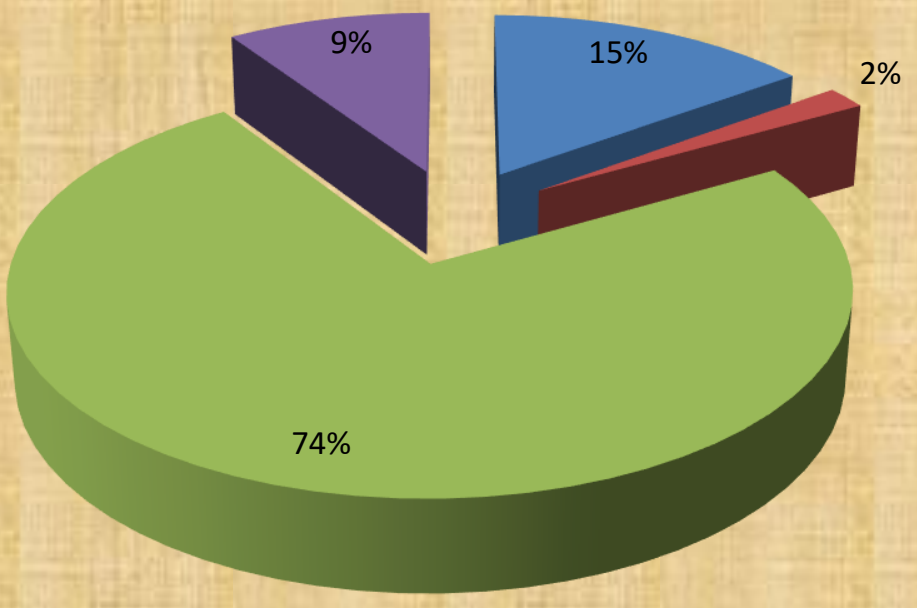

$\square$ YES

NO

MAYBE

MISSING

As shown in Figure 2,15\% of the participants indicated that they would visit the office again, whilst $2 \%$ of the $17 \%$ of participants who had visited the EAP before indicated that they would never visit the office again. On the other hand, $74 \%$ of the participants who have not visited the EAP office indicated that they might consider visiting the office in future. Nine percent $(9 \%)$ of the participants did not answer this question in the questionnaire. It could therefore be suggested that a minority of the employees within the SAPS at Lephalale have a negative attitude towards the programme and that it seems that marketing of the EAP does not fully penetrate the targeted consumers. This suggestion is prompted by the fact that the study showed that the programme is marketed but not used adequately and this has impacted on the overall effectiveness of the programme. The EA practitioner is encouraged to rethink the EAP marketing strategy to persuade the majority (74\%) to use the programme.

There was also a troubling percentage of employees who indicated that they would not consider visiting the EAP office again; this calls for further research to establish the reasons for such an assertion. Sharar, Pompe and Attridge (2013) and Leonard and Terblanche (2020) state that employees are less likely to visit the EAP if they suspect that their information will not be kept confidential, or that their problems will not be given priority. This could result in them losing trust in the EAP office, which would directly impact on the utilisation and possible effectiveness of the programme. 


\section{Visibility of EAP staff}

Table 2 indicates the SAPS employees responses concerning the visibility of EAP staff as a way of marketing their services.

TABLE 2: VISIBILITY OF EAP STAFF

\begin{tabular}{|l|l|l|}
\hline OPTION & N=107 & $\mathbf{1 0 0 \%}$ \\
\hline VISIBLE & 27 & 25 \\
\hline NOT VISIBLE & $\mathbf{7 7}$ & $\mathbf{7 2}$ \\
\hline SOMETIMES & $\mathbf{0 3}$ & $\mathbf{0 3}$ \\
\hline TOTAL & $\mathbf{1 0 7}$ & $\mathbf{1 0 0}$ \\
\hline
\end{tabular}

Table 2 shows the high number of respondents $(72 \%)$ who indicated that there is poor visibility of the EAP staff. The poor visibility of the staff will certainly negatively affect the employees' awareness of the programme and its subsequent utilisation. However, $25 \%$ of the participants indicated that the EAP staff is visible. Even though $25 \%$ showed that EAP staff is visible, it is worrying that these respondents do not use EAP services, even though they acknowledge its visibility. The visibility of the EAP can have a positive impact upon employee awareness, which in turn is related to its utilisation (Xavier, 2012; Taranowski \& Mahieu, 2013; Okemwa, Atambo \& Muturi, 2019). This implies that poor visibility of the EAP may result in its poor utilisation which, in turn, may result in the ineffectiveness of the programme.

\section{Employees' understanding of EAP's purpose}

Participating SAPS employees were requested to report on their understanding of the EAP and its purpose. The responses of the participants about whether they understood the EAP and its purpose are summarised in Figure 3 below.

\section{FIGURE 3}

\section{EMPLOYEES' UNDERSTANDING OF THE EAP AND ITS PURPOSE}

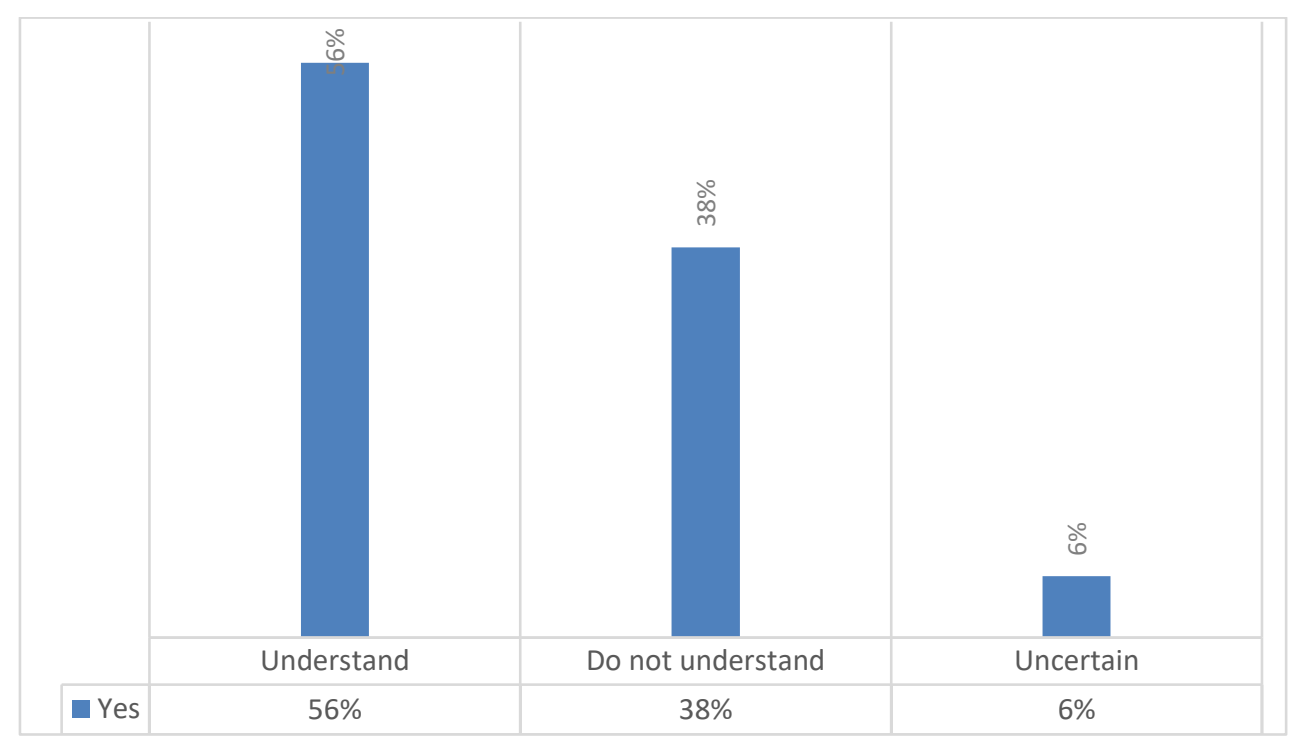

The histogram above (Figure 3) indicates that the majority of participants (56\%) understood the purpose of the EAP. This study revealed that there is a gap between employees who understand the EAP and those who do not, as $38 \%$ of the participants responded that they lacked understanding of the EAP. It is very concerning that there was such a high number of employees who did not understand the purpose of the EAP. Hence it is important for the EA practitioners to intensify dissemination of the EAP's purpose and function to employees. This calls for management, unions and the EAP officials to intensify the level of awareness campaigns and methods of distributing information about the EAP to all employees. It is the researcher's opinion that the more knowledgeable the employees are about the EAP's service, the 
more the utilisation rate will increase. The researcher further agrees with Taranowski and Mahieu (2013) and Attridge (2018) that there is a link between familiarity and understanding of the EAP's service and the rate of its utilisation. The authors further posit that the average number of visits to an EAP may be one indicator of a well-functioning programme (Attridge, 2018; Taranowski \& Mahieu, 2013).

\section{Knowledge of EAP services}

The researcher inquired about the employees' knowledge of different EAP services available within their workplace. The pie-chart below (Figure 4) highlights whether the employees have knowledge of EAP services.

FIGURE 4

KNOWLEDGE OF EAP SERVICES

\section{Knowledge of EAP services}

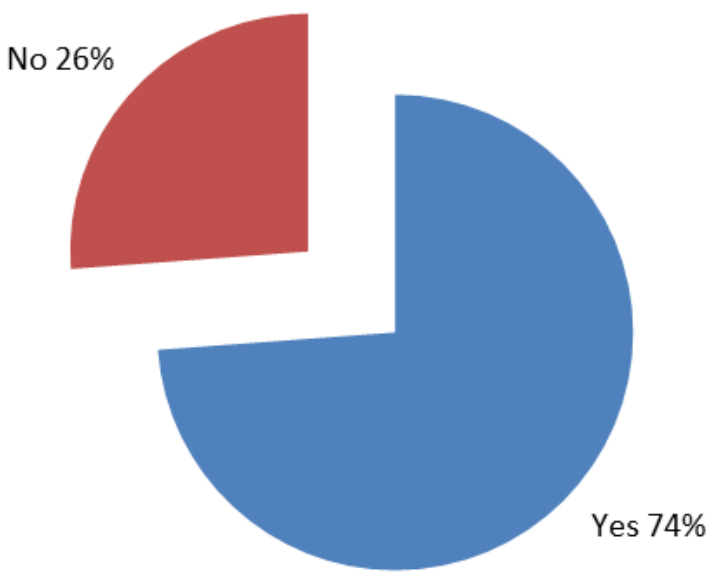

The majority of respondents (74\%) acknowledged that they were knowledgeable about services such as family preservation services and stress management rendered by the EAP. This may be because the majority of participants in this study were young and at a stage where most of them could be attempting to start families and may frequently require guidance and advice on family matters. In contrast, others may be experiencing workplace stress because of the nature of their work, which mostly involves attending to traumatic events. EAPs are designed to respond appropriately to the number and types of challenges experienced by employees such as alcohol and drug abuse, as well as personal, financial and family problems (Joseph, Walker \& Fuller-Tyszkiewicz, 2018; Milot \& Borkenhagen, 2018). Whilst the majority of employees within the Lephalale SAPS were knowledgeable about the services offered by the EAP, the rest of the participants (26\%) indicated that they were not informed about the kind of services offered by the EAP practitioner. It is also evident from the findings that being knowledgeable about the EAP does not automatically translate into increased utilisation of the service.

\section{Accessibility}

The pie-chart in Figure 5 depicts the employees' knowledge of the location of the EAP office and how this helps or hinders the utilisation of services.

FIGURE 5

DISTANCE OF EAP OFFICE 


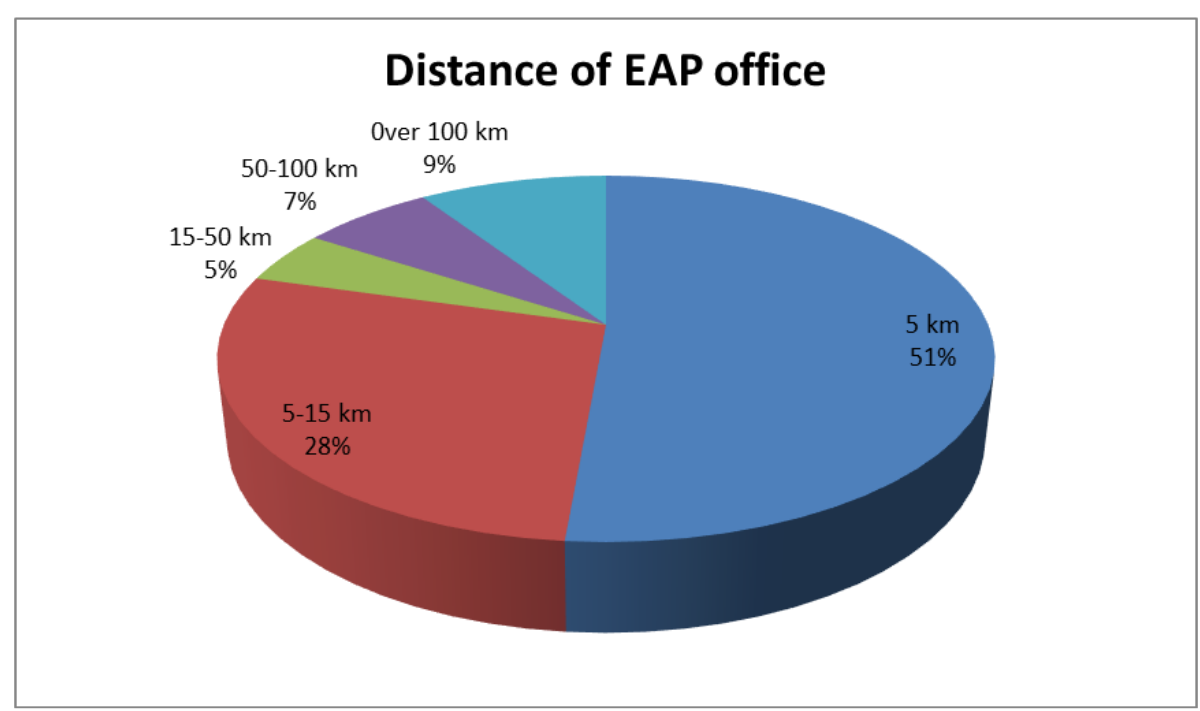

The majority of respondents indicated that they were within a reasonable distance $(5-15 \mathrm{~km})$ of the EAP office, meaning that the programme was physically accessible. However, a reasonable or short distance between the employee and the service point does not necessarily translate to increased utilisation. Accessibility of the programme relates both to the physical location of the programme as well as to the matter of confidentiality (that is where the programme is located and whether the location is conducive to confidentiality).

It was further noted that there was a lower percentage of participants (12\%) situated $15-100 \mathrm{~km}$ from the EAP's office, whereas a minority of participants (9\%) indicated that the distance was over $100 \mathrm{~km}$. The researcher is of the opinion that some of the employees, especially those who have to drive long distances to the EAP office, may be reluctant to report their personal concerns because of distance, which means they may decide to approach other government departments nearer to them that offer the services they need. The researcher agrees with Okemwa et al. (2019) and Attridge (2018) that it is important for employees to be able to reach the EAP in an immediate and convenient manner and within a reasonable driving or walking distance.

\section{Suitability of operational hours}

Employees reported on their views about the functioning and the suitability of the operational hours of the Lephalale SAPS EAP. Their views are captured in Figure 6.

\section{FIGURE 6}

SUITABILITY OF OPERATIONAL HOURS

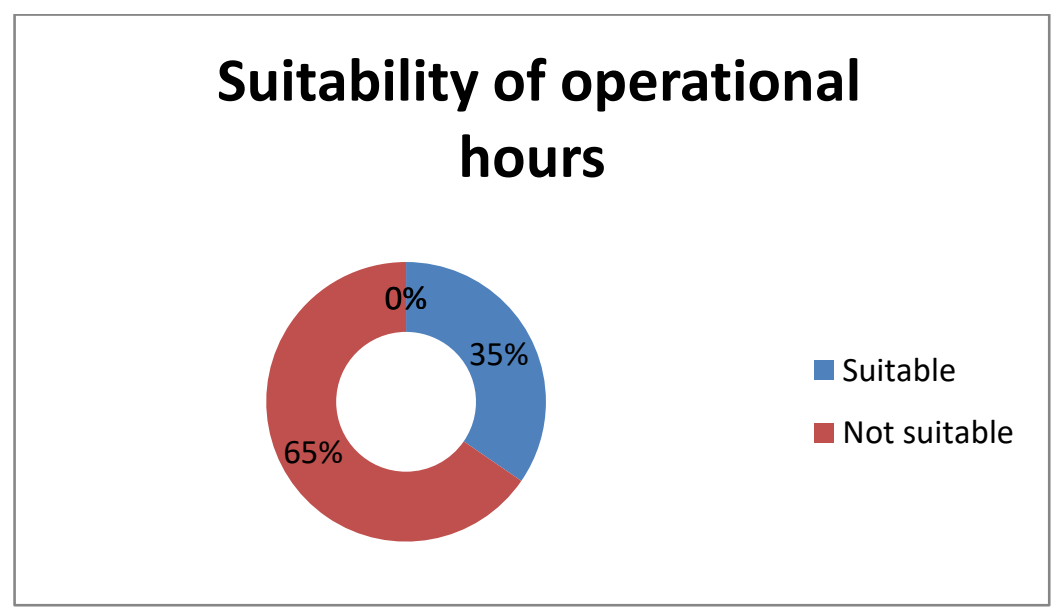

Figure 6 illustrates that most respondents (65\%) were not comfortable with the EAP's operational hours. This may reflect the experience of those employees who are employed in terms of the South African 
Police Service Act 68 of 1995 (RSA, 1995). It may be that they are not comfortable because most of them work the night shift and they may be in need of services after hours, when the EA practitioner is not available because the EAP office is only operational from 07h30-16h30 and is also closed on weekends and public holidays. A lower percentage of respondents $(35 \%)$ were comfortable with the operational hours. This may be because most of these persons were support staff employed in terms of the Public Service Act 103 of 1994 (RSA, 1994) and only work the day shift. The researcher agrees with Kurzman (2013); Cekiso and Terblanche (2015) and Maynard (2019) that employees should have access to the programme in a convenient and efficient manner, with serious and explicit consideration given to confidentiality. An accessible service is one that is located near the employees, open at convenient hours, maintains short waiting lists and has affordable charges (Lephalale SAPS EAP offers a free service to employees).

The fact that fewer employees were comfortable with the programme's operational hours than those who were uncomfortable is a major concern, as this would more than likely impact adversely on the programme's utilisation and effectiveness.

\section{Marketing of EAP services}

The researcher requested the respondents to report on their observation of strategies in place to market the EAP. The respondents' views about the marketing of the EAP services are summarised in Figure 7.

\section{FIGURE 7}

MARKETING OF EAP SERVICES

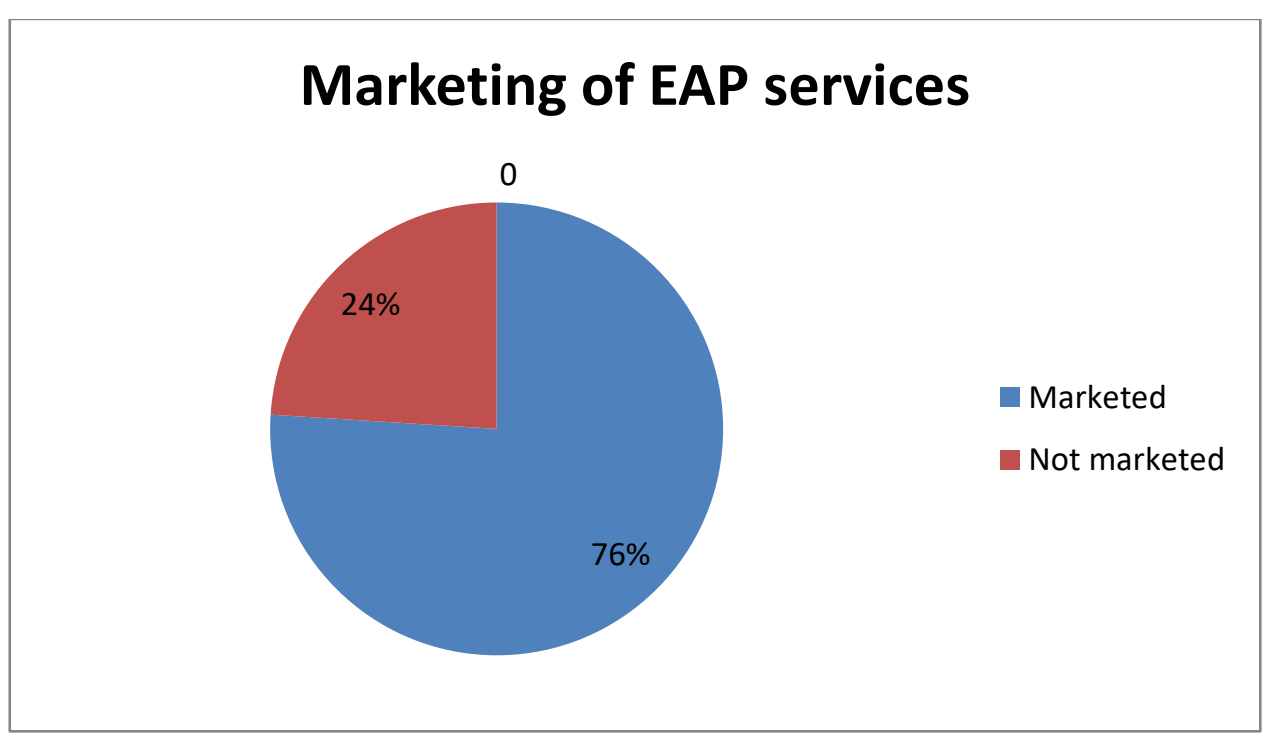

It is clear from Figure 7 that the majority of participants $(76 \%)$ indicated that they were aware of the marketing of the EAP. The fact that the majority of participants, those who indicated that they were aware that the services were marketed, did not use the service is a cause for concern. There may be a need to conduct further research to establish the reasons why the programme is not fully utilised, despite being visibly marketed. Perhaps respondents were just not comfortable in using the service within the organisation. Only $17 \%$ of participants used the service. A fairly large number of the participants who indicated that they were aware that EAP is marketed are those employees stationed $5-15 \mathrm{~km}$ from the EAP office. This may be because it was convenient for employees working or living in close proximity to the EAP office to access the EAP services. A higher percentage of respondents $(24 \%)$ clearly stated that the EAP services were not marketed to them and most of these respondents were stationed 50-100 $\mathrm{km}$ away from the EAP office. With reference to the marketing of EAPs, the Employee Assistance Professionals Association of South Africa (EAPA) stated that outreach programmes and the promotion of EAP services should be conducted constantly at all levels of the organisation as a way of ensuring employees are aware of the programme's availability (EAPA, 2011; Joseph \& Walker, 2017). 


\section{CONCLUSION AND RECOMMENDATIONS}

The purpose of the study was to report on the reasons why SAPS employees were not utilising internal EAP services available for Lephalale police stations. The sample was comprised of 189 respondents drawn from the total population of 397 SAPS employees. The results obtained showed that the EAP is well implemented within the Lephalale SAPS. It was clear that most respondents were familiar with the rationale for the existence EAP services within SAPS. The outcome of the study showed the further the distance of employees stationed away from the programme, the lesser the number of employees that utilised the programme. In short, the study revealed that the majority of employees in SAPS did not utilise EAP services.

Findings from this study revealed that employees certainly are aware of the existence of EAP services in their workplace. However, they appear to be reluctant to utilise the service. The majority of employees also indicated that the EAP office did not have enough personnel and a considerable number of those who had visited the EAP office before indicated they might not revisit the office in future. Moreover, some employees used the services provided by other government departments, which were more convenient for them. Doubtlessly, if large numbers of SAPS employees would rather seek outside services despite the EAP being available, the utilisation of the SAPS employment assistance programme will be affected negatively. Programme under-utilisation is a threat to the EAP's continued existence within the SAPS in Lephalale. Whereas the SAPS has invested financial and human resources in the programme, its under-utilisation may lead to this being regarded as a wasteful expenditure and the closure of the EAP.

Therefore, a number of recommendations are made below.

Consistent with the above findings, the EA practitioner is encouraged to rethink the EAP marketing strategy inter alia through improved staff visibility to persuade more employees to use the programme, since most employees are aware of the existence of the programme. A factor that emerged from this study is that awareness of the programme does not mean understanding and utilisation of the programme. SAPS's management should consider obtaining the services of more EAP staff to accommodate the large number of employees within the cluster. SAPS management should consider making available a 24/7 EAP toll-free hotline so that employees will have access to EAP services at any time. Due to the nature of the operation of the SAPS, which requires some of the employees to work night shifts, management should consider having EA practitioners who work night shift or who would be on standby in order to address the immediate needs of employees at night. All employees should be encouraged to participate in EAP policy development, especially during consultation and review processes. The policy document should form part of the marketing activities of the EAP, so that all employees are aware of its contents, goal and purpose and can contribute to it. Evaluation of the implementation of the programme could be facilitated by suggestion boxes, focus groups and benchmarking with other institutions. Encouraging employees to submit suggestions, input and feedback will promote improvement in the programme and increase employees' buy-in.

It is hoped that the findings of this study may be helpful to EAP practitioners in gaining more information and knowledge about the evaluation of an EAP. The outcome of the study will assist SAPS EAP practitioners and management to review, adjust and rethink the method and format of rendering EAP services to their employees, which could lead to an improvement in the lives of individuals, families and communities.

\section{REFERENCES}

ABDULLA, J., DJEBARNI, R. AND MELLAHI, K. 2011. Determinants of job satisfaction in the UAE: Case study of the Dubai police. Personnel Review, 40(1): 126 - 146.

ATTRIDGE, M. 2018. A global perspective on promoting workplace mental health and the role of employee assistance programs. American Journal of Health Promotion, 33(4): 33-38. 
BLESS, C., HIGSON-SMITH, C. \& SITHOLE, L. 2013. Fundamentals of social research methods: an African perspective. $5^{\text {th }}$ ed. Cape Town: Juta \& Company.

CEKISO, N. A. \& TERBLANCHE, L. S. 2015. Pricing models of employee assistance programs: Experiences of corporate clients serviced by a leading employee assistance program service provider in South Africa. Journal of Workplace Behavioural Health 30(1-2): 154-178.

CSIERNIK, A. \& CSIERNIK, R. 2012. Canadian employee assistance programming: An overview. Journal of Workplace Behavioural Health, 27(2): 100-116.

DE VOS, A. S., STRYDOM, H., FOUCHÉ, C. B. AND DELPORT, C. S. L. 2011. Research at grass roots: For the social sciences and human service professions. $4^{\text {th }}$ ed. Pretoria: Van Schaik.

DIMOFF, J. K. \& KELLOWAY, E. K. 2019. With a little help from my boss: The impact of workplace mental health training on leader behaviors and employee resource utilization. Journal of Occupational Health Psychology, 24(1): 4-19.

EMPLOYEE ASSISTANCE PROFESSIONALS ASSOCIATION (EAPA). 2011. Definitions of an employee assistance program (EAP) and EAP core technology. [Online] Available: https://www.shrm.org/hrtoday/news/hrmagazine/pages/1110grossman7.aspx (Accessed 2013/03/02).

FREY, J. J., POMPE, J., SHARAR, D., IMBODEN, R. \& BLOOM, L. 2018. Experiences of internal and hybrid employee assistance program managers: Factors associated with successful, at-risk, and eliminated programs. Journal of Workplace Behavioral Health, 33(1): 1-23.

GROBLER, A., JOUBERT, Y. T. 2012. Expectations, perceptions and experience of EAP services in the SAPS. Journal of Contemporary Management, 12(9): 150-153.

JACOBSON, J. M., JONES A. L. \& BOWERS, N. 2011. Using existing employee assistance program case files to demonstrate outcomes. Journal of Workplace Behavioural Health, 26(1): 44-58.

JOHNSON, D. J. 2011. Employee assistance programs: Sources of assistance relations to inputs and outcomes. Journal of Workplace Behavioural Health, 23(3): 263-282.

JOSEPH, B. \& WALKER, A. 2017. Employee assistance programs in Australia: The perspective of organisational leaders across sectors. Asia Pacific Journal of Human Resources, 55(11): 177-191.

JOSEPH, B., WALKER, A. \& FULLER-TYSZKIEWICZ, M. 2018. Evaluating the effectiveness of employee assistance programmes: A systematic review. European Journal of Work and Organizational Psychology, 27(1): 1-15.

KURZMAN, P. A. 2013. Employee assistance programs for the new millennium: Emergence of the comprehensive model. Journal of Social Work Mental Health, 4(2): 28-41.

LEEDY, P. D. \& ORMROD, J. E. 2005. Practical research: Planning and design. $8^{\text {th }}$ ed. Ohio: Merrill Prentice Hall.

LEONARD, M. \& TERBLANCHE, L. S. 2020. An employee assistance programme for small and medium enterprises in Namibia - A needs assessment. Social Work/Maatskaplike Werk, 56(1): 1-12.

MARK, M. M., HENRY, G. T. \& JULNES, G. 2000. Evaluation: An integrated framework for understanding, guiding and improving public and non-profit policies and programmes. San Francisco: Jossey-Bass.

MAYNARD, J. 2019. World of EAP column: EAP in the Philippines - On the cusp of change. Employee Assist, 48(1): 14-15.

MCCLEDON, M. J. 2004. Statistical analysis in the social sciences. Belmont: Thompson Wadsworth. MERGA, M. K., \& RONI, S. 2018. Characteristics, preferences and motivation of avid non-fiction readers. Collection and Curation, 37(2): 50-59. 
MILOT, M. \& BORKENHAGEN, E. 2018. Job stress in users of an employee assistance program and association with presenting status. Journal of Workplace Behavioural Health. [Online] Available: http://doi.org/10.1080/15555240.2018.1502044 (Accessed 2019/04/25).

MISHRA, P., PANDEY, C. M., SINGH, U., GUPTA, A., SAHU, C. \& KESHRI, A. 2019. Descriptive statistics and normality tests for statistical data. Ann Card Anaesth, 22(1): 67-72.

MOHAJANE, M. P. 2017. Job satisfaction and employee retention in the South African Police Service. Pretoria: University of South Africa. (Doctoral thesis)

OKEMWA, D. O, ATAMBO, W. N, \& MUTURI, W. M. 2019. Influence of employee assistance programs on commitment of nurses in public hospitals in Kenya. International Journal of Academic Research in Business and Social Sciences, 9(1): 151-164.

RAJIN, J. 2012. Employee assistance programme in the South African Police Service: A case study of Moroka police station. Administration. Pretoria: University of South Africa. (MTech thesis)

REPUBLIC OF SOUTH AFRICA (RSA). 1995. South African Police Service Act 68 of 1995. Government Gazette, Vol. 364, No. 16731 (13 October 1995). Pretoria: Government Printer.

REPUBLIC OF SOUTH AFRICA (RSA). 1994. Public Service Act 103 of 1994. Government Gazette, Vol. 348, No. 15791 (1 June 1994). Pretoria: Government Printer.

ROSSI. P. H., LIPSEY, M. W. \& FREEMAN, H. E. 2004. Evaluation: A systematic approach. $7^{\text {th }}$ ed. Thousand Oaks: Sage.

RUTBERG, S. \& BOUIKIDIS, C. D. 2018. Focusing on the fundamentals: A simplistic differentiation between qualitative and quantitative research. Nephrology Nursing Journal, 45(2): 209-212.

SATTIGERI, R. C. 2016. Employee retention and commitment. International Journal of Engineering Technology, Management and Applied Sciences, 4 (4): 77-81.

SHARAR, D., POMPE, J. C. \& ATTRIDGE, M. 2013. Onsite versus offsite EAPs: A comparison of workplace outcomes. Journal of Employee Assistance, 43(2): 1-4.

STONE, R. 2011. Human resource management. $7^{\text {th }}$ ed. Milton, UK: Wiley- Blackwell.

TARANOWSKI, C. J. \& MAHIEU, M. M. 2013. Trends in employee assistance program implementation, structure, and utilization, 2009 to 2010. Journal of Workplace Behavioral Health 28(3): 172-191.

XAVIER, M. 2012. Initiating employee assistance program (EAP) for a corporate: An experiential learning. Journal of Organizational Behaviour, 11(2): 16-44.

YAN, L. \& YAN, J. 2013. Leadership, organisational citizenship behavior, and innovation in small business: An empirical study. Journal of Small Business and Entrepreneurship 26(2): 183-199.

ZENG, Z., GUO, Y., LU, L., HAN, L., CHEN, W. \& LING, L. 2014. Mental health status and work environment among workers in small and medium-sized enterprises in Guangdong, China: A crosssectional survey. BMC Public Health 22(14): 1162. 